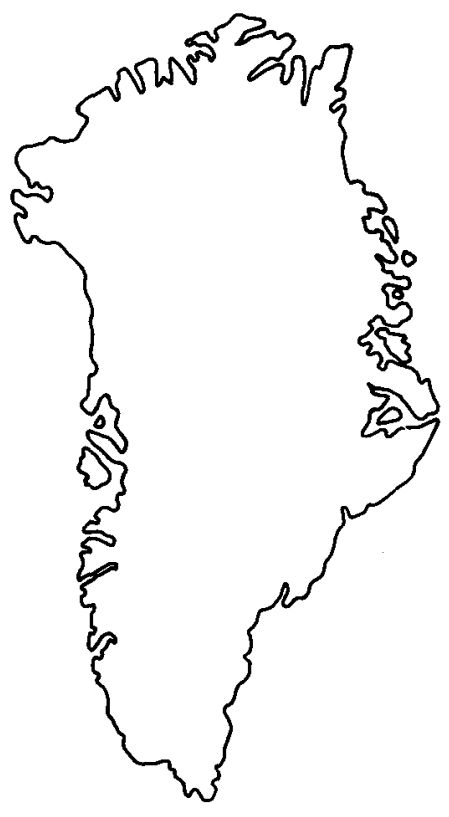

\title{
Facies mapping and reservoir evaluation of the Upper Permian Wegener Halvø Formation along the western margin of the Jameson Land basin, East Greenland
}

\author{
Lars Stemmerik, Peter A. Scholle, \\ F. H. Henk, Giuseppe Di Liegro, \\ Marco Mantovani and Dana S. Ulmer
}

\begin{abstract}
The depositional pattern of the Upper Permian Wegener Halvø Formation is mainly controlled by the karst topography of the surface of the underlying Karstryggen Formation. The area was divided by a NNW-SSE trending depositional and/or erosional high during Late Permian times. Peritidal carbonates and evaporites are dominant on the platform to the west while to the east oolite and biogene grainstone deposits dominate.

Reservoir-quality properties are mainly confined to the grainstone deposits east of the high.

L. S., Geological Survey of Greenland, Øster Voldgade 10, DK-1350 Copenhagen K, Denmark.

P. A. S. \& D. S. U., Department of Geological Sciences, Southern Methodist University, Dallas, Texas 75275, U.S.A.

F. H. H., ARCO International Oil and Gas Company, P. O. Box 260888, Plano, Texas 75026-0888, U.S.A.

G. D. L. \& M. M., AGIP, P. O. Box 12069, 20120 Milano, Italy.
\end{abstract}

Field work in the summer of 1989 was a continuation of the joint ARCO, AGIP and GGU programme initiated in 1988 to evaluate the reservoir potential of the Upper Permian limestones along the margins of the Jameson Land basin (Stemmerik et al., 1989). The field work, carried out from a Bell 206 helicopter, was concentrated on the Karstryggen plateau along the western basin margin (fig. 1).

Published studies on Upper Permian limestones in the Karstryggen area (Stemmerik, 1980; Surlyk et al., 1984a,b, 1986) and the results of the 1988 studies along the eastern basin margin, all indicate that reservoir properties are expected to occur mainly in the Wegener Halv $\emptyset$ Formation. Accordingly, the 1989 programme focused on detailed facies mapping of this formation.

\section{Facies mapping}

The facies mapping attempted to establish an internal stratigraphy for the carbonate platform sequence. It was found that the facies distribution and stratigraphy was more complex than previously thought, and that the depositional pattern was controlled mainly by the karst topography of the underlying Karstryggen Formation surface.

\section{Pre-depositional topography}

The surface of the Karstryggen Formation forms the most impressive sequence boundary on the Karstryggen carbonate platform. This horizon defines a mature karst or surface drainage system. Karst relief, in places, exceeds $100 \mathrm{~m}$, with pinnacle-like as well as sink-hole morphologies. To the northwest there is evidence also of through-going drainage and dissection of the Karstryggen Formation (fig. 2). The most striking morphological feature is an erosional or depositional high which cuts across the platform, trending NNW-SSE (fig. 3). Areas to the west of this high generally were topographically higher than areas to the east and accordingly, distinctively different sediments were deposited across this high during deposition of the Wegener Halvø Formation (fig. 4). This topographic difference was further enhanced by partial infill of the sink-holes 


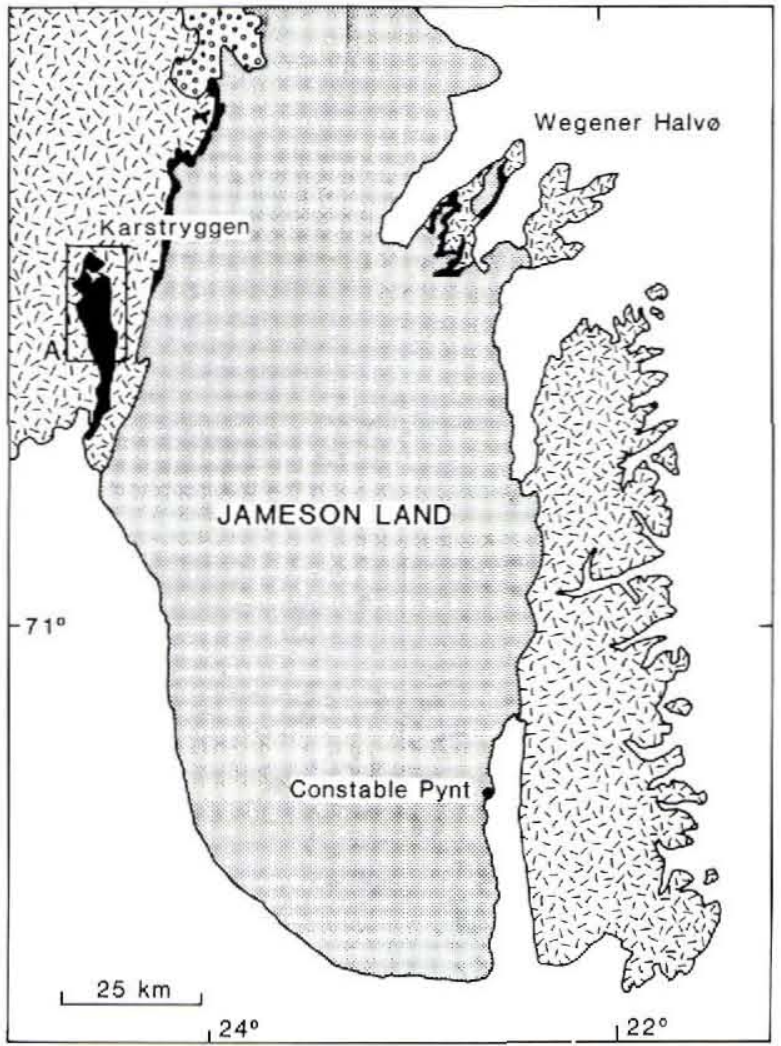

$\because \because$ Tertiary intrusions

$\therefore \begin{aligned} & \text { Cretaceous to } \\ & \text { Triassic }\end{aligned}$

Fig. 1. Map of Jameson Land showing distribution of Upper Permian sediments and the area of investigation.

on the western platform by collapse breccia prior to the transgression that led to deposition of the Wegener Halvø Formation.

\section{Eastern facies belt}

The dominant strata in the eastern facies belt are bedded oolitic, oncolitic and gastropod grainstones. In- dividual beds may be massive, graded or cross-bedded (fig. 5), and clearly these facies represent a variety of depositional environments. From field evidence it is obvious that the main site for carbonate production was the topographic highs of the underlying Karstryggen Formation surface. The carbonates prograded into surrounding lows in a complex fashion.

In the latest stages of platform development fossiliferous packstones and wackestones with a normal marine fauna of bryozoans, brachiopods and crinoids were deposited. Apparently, the karst relief by this time was levelled out with the exception of a few deep channels, and more uniform and open marine conditions prevailed. The packstone facies form small, isolated, crossbedded mounds surrounded by wackestones.

The depositional history of the area is briefly summarized as follows. During the initial stages of the Wegener Halvø Formation transgression, evaporites were deposited in small basins formed in the deepest sinkholes. Oolitic shoals were developed on karst pinnacle crests and upper flanks. These shoals and the detritus shed from the shoals prograded with time across the topographic lows and partially filled them. Deeper-water fossiliferous wackestones were initially restricted to the deeper sink-holes where they directly overlie the evaporites. Later in the platform history this facies became more widespread and most likely covered most of the eastern area. The youngest part of the depositional sequence is, however, only preserved in the northeastern part of the Karstryggen plateau. Here, brachiopod wackestones overlie the grainstones, and are themselves overlain by small cross-bedded mounds with a normal marine fauna (Surlyk et al., 1986).

\section{Western facies belt}

The western sedimentary section consists of a complex series of cyclically-bedded shallow subtidal, intertidal and supratidal facies. A typical sequence includes dark, thin- to medium-bedded molluscan packstones and wackestones overlain by intertidal algal stromato-

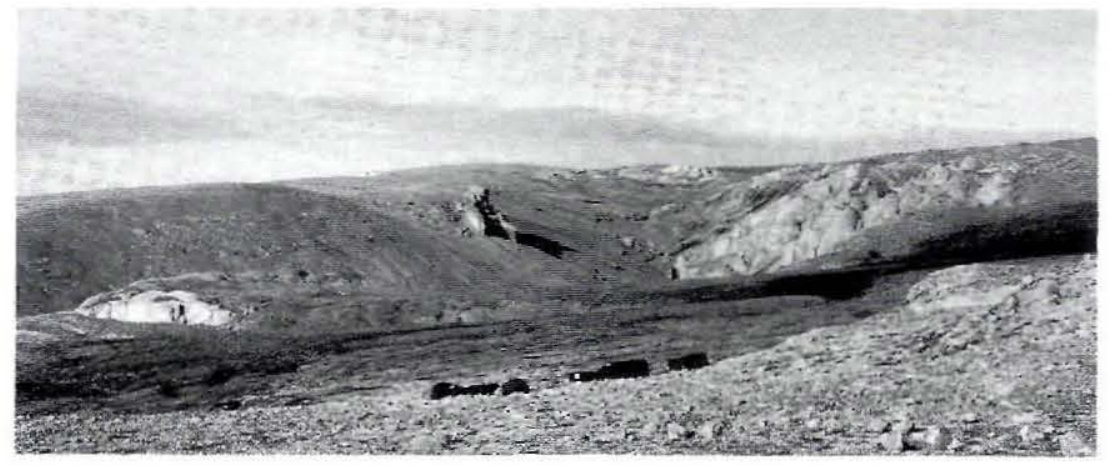

Fig. 2. Wegener Halvø Formation sediments (grainstones and sandstones) filling in an approximately $150 \mathrm{~m}$ deep palaeo-valley following the present valley in the centre of the photograph. 


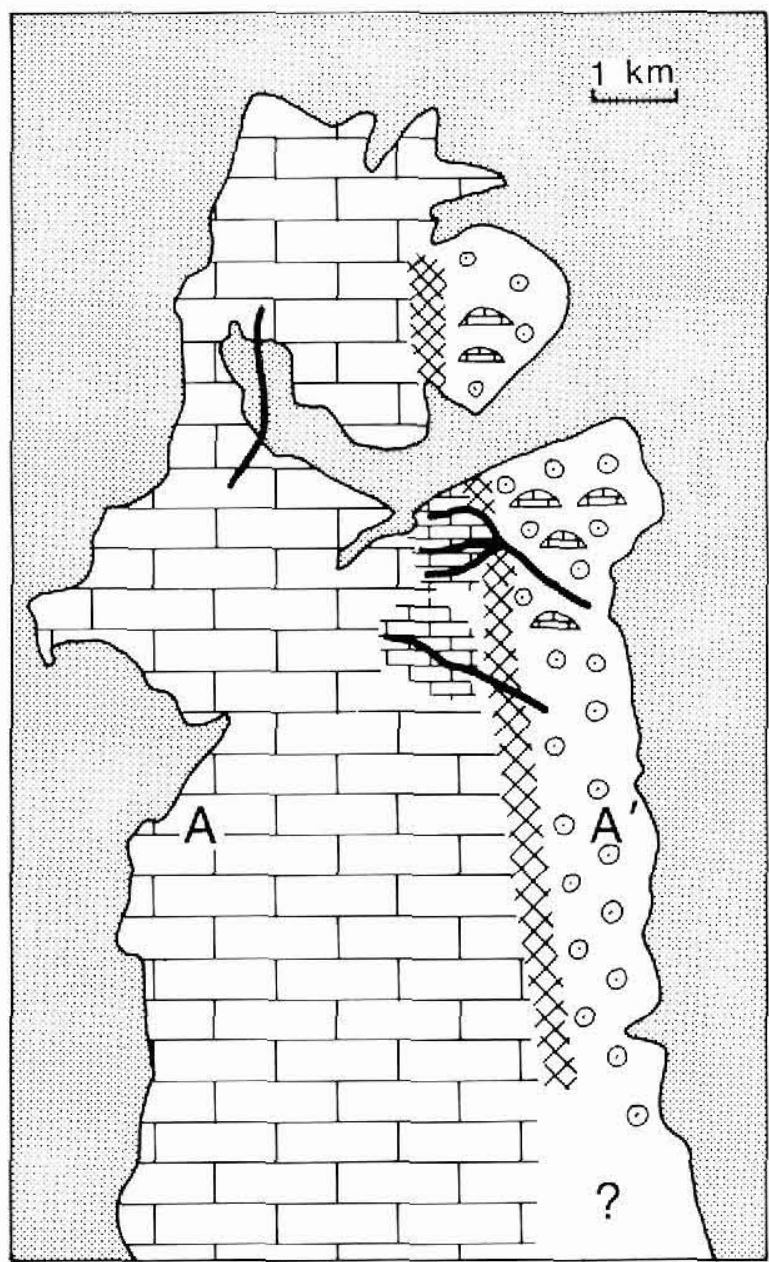

WEGENER HALVØ FORMATION
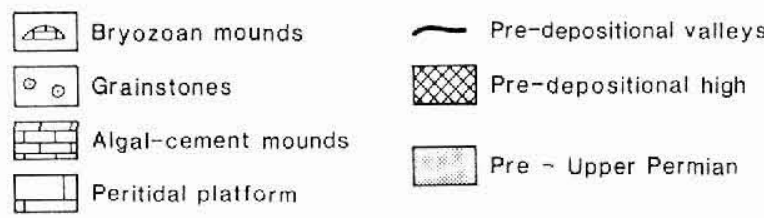

Fig. 3. Detailed map of the Karstryggen plateau showing facies distribution within the Wegener Halvø Formation. For location see fig. 1 . lites, and capped with reddish, brecciated and contorted beds sometimes containing tepee structures and pisoids or, more commonly, bearing evidence of former evaporites. Lateral variability of facies and thickness of individual beds is obvious and appears controlled by the underlying sink-hole morphologies (fig. 6).

\section{Platform stratigraphy}

In general, the entire Wegener Halvø Formation thins to the west so that it is $20-30 \mathrm{~m}$ thick there while more than $150 \mathrm{~m}$ thick to the east (fig. 4). The western facies belt is marked by three prominent reddened surfaces which can be followed regionally. The lowest of these is less continuous than the two upper surfaces, but all three units apparently pinch out against the topographic high. East of the high, two or possibly three units of red and yellowish terrigenous sand are laterally widespread. We suggest that these sandy intervals represent marine reworked fluvial sand transported across the western platform during minor (intra-Wegener Halvø Formation) sea-level low stands and that these horizons correlate with the reddened surfaces on the western platform. These reddened surfaces and terrigenous sandstones thus provide important stratigraphic tools for developing a more detailed understanding of the depositional history of the Karstryggen area.

\section{Reservoir evaluation}

Reservoir-quality properties are mainly confined to the grainstones found in the lower part of the eastern facies belt. From field evidence it is judged that these grainstones were subjected to early leaching of aragonite grains. This process most likely was related to meteoric flushing of the area during the sea-level low stands recorded by the thin sandstones.

The combination of the thickness of the grainstones, up to $150 \mathrm{~m}$, their lateral continuity along the entire length of the Karstryggen plateau, and the early leaching and secondary porosity development, all point to
Fig. 4. Schematic cross section along line $\mathrm{A}-\mathrm{A}^{\prime}$ in fig. 3 showing palaeo-relief of the Karstryggen Formation and facies distribution within the Wegener Halvø Formation.

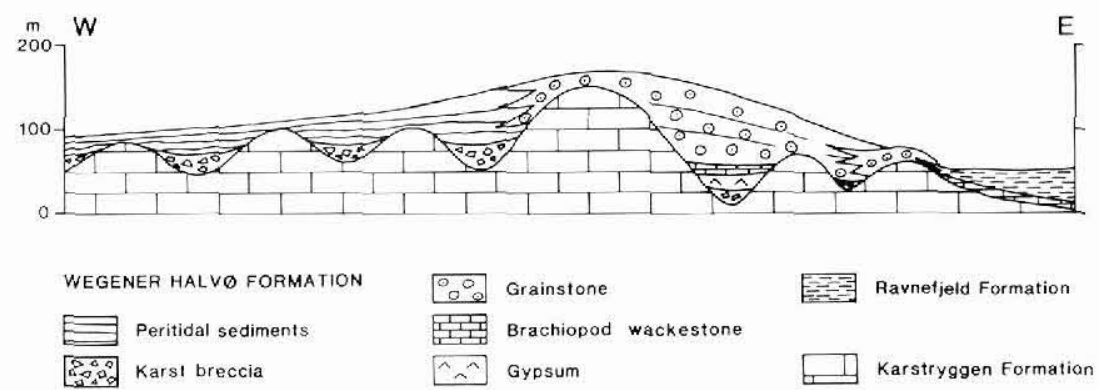




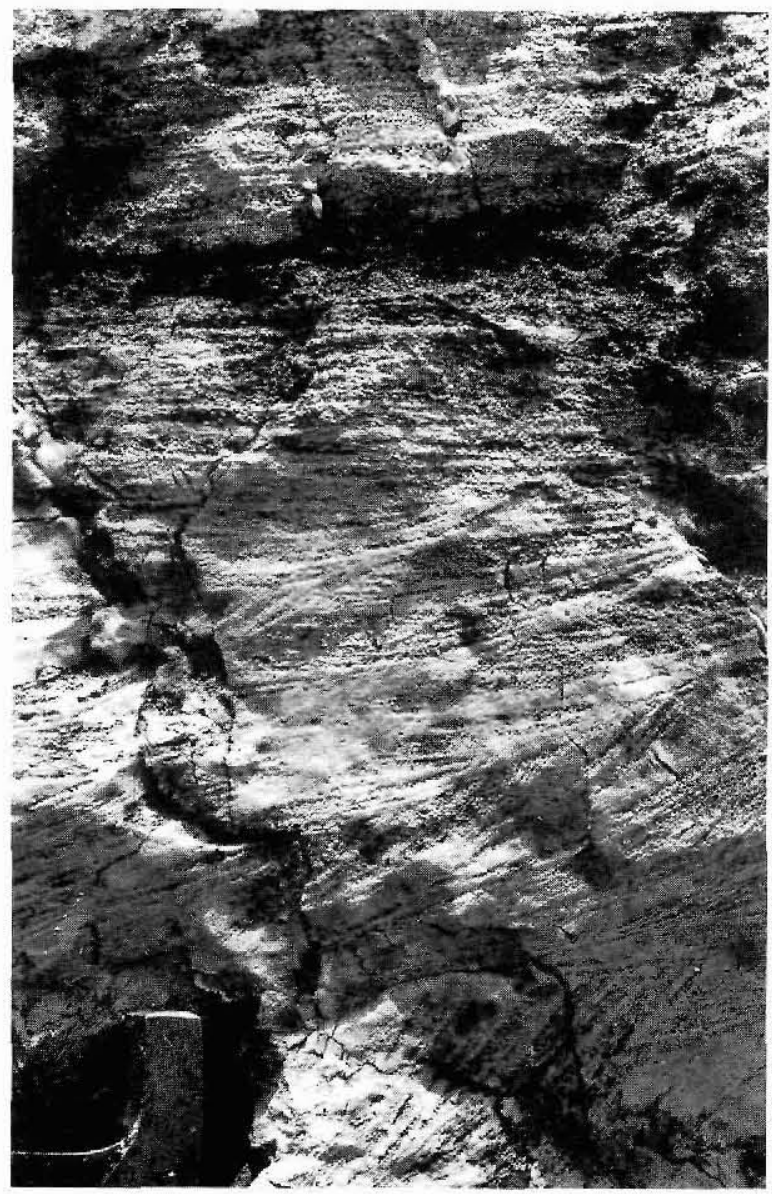

Fig. 5. Cross-bedded oolitic grainstone. Hammer for scale. this facies type being a potential reservoir in the Jameson Land basin.

\section{References}

Stemmerik, L. 1980: Observations on Upper Permian sediments in southern Scoresby Land, East Greenland. Rapp. Grønlands geol. Unders. 100, 105-107.

Stemmerik, L., Scholle, P. A., Thomas, E., Amendolia, M., Henk, F. H. \& Uncini, G. 1989: Facies mapping and reservoir evaluation of the Upper Permian Wegener Halvø Formation in Wegener Halvø, East Greenland. Rapp. Grønlands geol. Unders. 145, 84-87.

Surlyk, F., Hurst, J. M., Marcussen, C., Piasecki, S., Rolle, F., Scholle, P. A., Stemmerik, L. \& Thomsen, E. 1984a: Oil geological studies in the Jameson Land basin, East Greenland. Rapp. Gronlands geol. Unders, 120, 85-90.

Surlyk, F., Piasecki, S., Rolle, F., Stemmerik, L., Thomsen, E. \& Wrang, P. 1984b: The Permian basin of East Greenland. In A. M. Spencer et al. (edit.) Petroleum geology of the North European margin, 303-315. London: Graham \& Trotman.

Surlyk, F., Hurst, J. M., Piasecki, S., Rolle, F., Scholle, P. A., Stemmerik, L. \& Thomsen, E. 1986: The Permian of the western margin of the Greenland Sea - a future exploration target. In M. T. Halbouty (edit.) Future petroleum provinces of the world. Am. Assoc. Petrol. Geol. Mem. 40, 629-659.

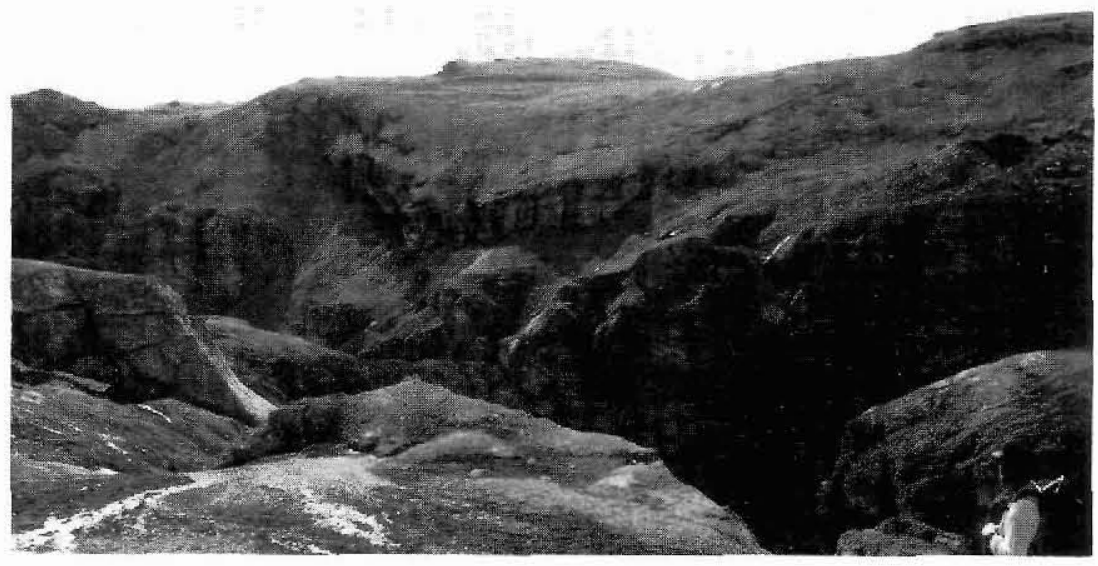

Fig. 6. Peritidal platform carbonates showing depositional draping (A) over partly infilled sinkholes (below A). 